\title{
Goran Kalogjera
}

\section{ODNOS PREMA SLOBODI, TIRANIJI I EUROPSKIM SILAMA U DJELIMA IVANA MAŽURANIĆA I ĐORĐIJA PULEVSKOG}

\author{
Pregledni rad \\ Review article \\ UDK 821.163.42.09 Mažuranić, I. \\ 821.163.3.09 Pulevski, G. \\ 821.163.42.091:821.163.3 \\ 821.163.3.091:821.163.42
}

Premda se Ivan Mažuranić, hrvatski pjesnik i ban, i Đorđija Pulevski, mijački zidar i ustanički vojvoda, nikada nisu u svojim životima susreli, osobnim su primjerom kao časni ljudi i pjesnici u svojim djelima slali univerzalne poruke o pravu svakog naroda na slobodu, vjeru, jezik i državu.

Ključne riječi: poema, epski spjev, Pulevski, Mažuranić, Turci, „Makedonska pesnarka“, „Samovila makedonska“, „Smrt Smail-age Čengića“, Europa

Predstavnik izrazite makedonističke orijentacije u konglomeratu makedonskoga lutanja po pitanju nacionalnoga određenja bio je svakako mijački zidar, pečalbar, vojnik, ustanik, kasnije gramatičar, folklorist, pjesnik i povjesničar Đorđija Pulevski (1820. 1895.). ${ }^{1} \mathrm{O}$ tome da je doista rođen u Galičniku svjedoči u svojem „Rječnikom od tri jezik“, kojem je uz prezime i ime pridodao „Mijak galjički“. ${ }^{2}$ Puleski ulazi u onu grupu makedonskih rodoljuba koji se nisu libili javno i glasno izraziti svoju pripadnost makedonskome narodu. Predstavlja skupinu domoljuba koji se posljednjih dvadeset godina 19. stoljeća javno deklariraju Makedoncima, svoju domovinu nazivaju Makedonijom i ulažu silne napore da se ideja o neovisnoj i slobodnoj Makedoniji konačno i realizira.

\footnotetext{
${ }^{1}$ Polenaković pretpostavlja da se možda rodio i desetak godina kasnije, negdje oko 1838. godine, uz naznaku da je njegov život nedovoljno poznat. Vidi u: Mijački leksikograf Đorđe M. Puljevski, "Glas Juga", Skopje, 1941., str. 31.

2 Blaže Ristovski, Đorđija M. Pulevski i negovite kniški "Samovila makedonska" i "Makedonska pesnarka", Institut za folklor, Skopje, 1973., str. 11.
} 
Ivan Mažuranić (1814. - 1890.) predstavlja obrazovanog, mudrog, vrijednog i talentiranog intelektualca, predstavnika hrvatskoga mladog građanstva, koji tijekom svoje karijere postaje jedan od najvažnjih hrvatskih političara u domovini i bečkoj kancelariji. Naprednih pogleda, poliglot, zakonadavac, pisac umnih i bitnih rasprava, književnik, postaje i hrvatski ban iz pučkih redova. Zalagao se za društvene i političke reforme sukladno zapadnoeuropskim društvima. Politički pripadao je manjini hrvatskih intelektualaca koji su se zalagali za uže veze Hrvatske s Bečom. ${ }^{3}$

Đorđija Pulevski djeluje u izrazito turbulentnome vremenu na južnim prostorima Balkana. ${ }^{4}$ To je doba učestalih ratova, buna, ustanaka, političkih dogovora, formiranja novih država, slabljenju Turskoga Carstva, ali i bujanja srpskih i bugarskih pretenzija prema makedonskim teritorijima. Kronološki slijediti njegov avanturistički život nemoguće je jer postoje velike praznine u njegovoj biografiji. ${ }^{5}$ Po zanatu zidar, koji je očito u pečalbi među majstorima i naučnicima naučio pisati i čitati, karakterno odvažan, smion i pustolovan, Pulevski je svojevrsna lutalica po balkanskim prostorima i njihovim centrima u kojima je uvijek ostavljao traga. Ti su tragovi ponekad bili i krvavi, jer je Pulevski još kao mladi makedonski komita izučio vojnički zanat te je slijedeći svoj buntovnički karakter i omrazu protiv Turaka sudjelovao u nizu ratova i buna protiv njih, počevši kao narednik u Tursko-srpskom ratu pa sve do vojvode u Kresnenskom ustanku. ${ }^{6} \mathrm{~S}$ obzirom na djela koja je napisao i koja su od vitalne važnosti za razvoj makedonske nacionalne misli, nameće se pitanje gdje je taj mijački zidar i ustanički vojvoda uspio akumulirati potrebito znanje da bi krenuo u ispisivanje dva rječnika, gramatike, nacionalne povijesti i niza drugih djela koja se smatraju prekretnicama u povijesti makedonskoga naroda. ${ }^{7}$

3 Pogledati: Antun Barac, Mažuranić (monografija), Zagreb, 1945.; Milorad Živančević, Ivan Mažuranić (monografija), Novi Sad, 1964.

${ }^{4}$ Ime Pulevskog nalazimo u literaturi u nekoliko različitih oblika: Đorđe, Đorđi, Georgi, Georgij, Đorđija, kao i inačice prezimena od Pulevski do Puljevski. Suvremena makedonska literatura donosi ime Đorđija i prezime Pulevski.

${ }^{5} \mathrm{Na}$ temelju rada akademika Blaže Ristovskog - Đorđija M. Pulevski i negovite kniški „Samovila makedonska" i "Makedonska pesnarka", Skopje, 1973. U njoj se može pronaći dosta novijih podataka o Pulevskom, pogotovo kao ustaniku, stoga svesrdno preporučujemo taj rad svim onima koji žele doznati nešto više o političkom, književnom, vojnom i udžbeničkome radu Pulevskog.

${ }^{6}$ Sudjelovao je u Tursko-srpskom ratu kao narednik u makedonskoj četi u srpskoj vojsci u obrani Beograda, bio je sudionik Rusko-turskog rata, te je sudjelovao u oslobođenju Sofije, gdje je dobio orden „Sv. Đorđe“ od ruskog cara. Bio je sudionikom u činu vojvode u napadu na turski garnizon u Kresni, ustanku koji se proširio na cijelu istočnu Makedoniju.

${ }^{7}$ Rečnik četiri jezika (Četirijazičnikot), Beograd, N. Stefanović i Družina, 1873., Rečnik od tri jezika, kniga druga, napisao Đ. M. Puleski. 
Mažuranić započinje svoju karijeru intelektualca kao suplent u zagrebačkoj gimnaziji. Nakon položenoga odvjetničkog ispita, ženi se Rozom, sestrom Dimitrije Demetera, prelazi u Karlovac gdje radi kao odvjetnik. Godine 1848. ulazi u politički život Hrvatske, kao narodni zastupnik u općinama Draganići i Cvetkovići. Nakon sloma revolucije stupa u državnu službu i penje se na hijerarhijskoj ljestvici državnih činovnika. Bio je državni odvjetnik u Zagrebu, hrvatski dvorski kancelar, zastupnik u saboru, hrvatski ban. $U$ životu Hrvatske ostavio je brojne pozitivne tekovine. Pod njegovom upravom u Hrvatskoj je uređeno osnovno i srednje školstvo, osnovano sveučilište, organizirana administracija. ${ }^{8}$

U razdoblju Kresenskoga ustanka i Berlinskoga kongresa Pulevski u Sofiji izdaje zbirku pjesama pod nazivom „Makedonska pesnarka“ i kao samostalno izdanje poemu „Samovila Makedonska“. 9 S tom zbirkom osobnih i narodnih pjesama Pulevski se predstavio čitateljima kao autor prve makedonske zbirke revolucionarnih pjesama. Zbirka „Makedonska pesnarka“ („Plačenje makedonsko“, „Makedoncim u prilog“, „Žaljost makedonska“, „Tri vojvodi“, „Tri krovača“, „Čelnik Dimo“, „Svjati Nikola“, „Bitoljka“, „Stojan vojvoda“, „Žaljost Neguška“, „Iskušenie - vernost“, „Zlata“, „Diljba“, „Kraljska“, „Zdravica“), odražava ideologiju i aktivnosti makedonskih sudionika Kresneskog ustanka. Naslovi zbirke i poeme nose jasne nacionalne oznake, a u pjesmi „Plačenje makedonsko“ jedanaest puta spominje riječ Makedonac i jednom makedonski. Prve tri pjesme u zbirci tiskane su crkvenoslavenskim ćiriličnim slovima, a ostale su pjesme tiskane građanskom ćirilicom s azbukom i pravopisom iz njegove "Rečnice slogovske“. Najzanimljivija mu je svakako podulja pjesma „Plačenje makedonsko“, koja se sastoji od 46 neujednačenih stihova. Nešto kasnije Pulevski kao poseban tisak objavljuje i poemu „Samovila Makedonska“, koja je napisana u šesnaestercu i u očitoj maniri uskipjele nacionalne romantike. Inspirirana je Sanstefanskim dogovorom i Berlinskim kongresom, koji su bili poražavajući za Makedoniju, jer jedino njezin status nije bio politički riješen. Tiskana građanskom ćirilicom s azbukom „Rečnice slogovske“, „Samovila Makedonska“ bila je vrlo popularna u svoje vrijeme jer je predstavljala opće stanje duha nezadovoljnih Makedonaca. O pjesmi su vrlo povoljno pisali besarabijski znanstvenik P. D. Draganov i Kuzman Šapkarev. ${ }^{10}$

Mažuranićev književni rad nije opsegom velik, ali je literarno, jezično i estetski najvrjednije što su ilirci mogli dati u svoje vrijeme. Pritom naravno mislimo na spjev „Smrt Smail-age Čengića“ i nadopune 14. i 15. pjevanja Gundulićeva „Osmana“. Od 1835. do 1848. godine objavio je Mažuranić u „Danici“ nekoliko pjesama, aforizama, crtica,

\footnotetext{
${ }^{8}$ Antun Barac, Hrvatska književnost, Knjiga 1., Književnost ilirizma, Zagreb, 1964.

9 „Makedonska pesnarka od Đorđija Pulevski“, Sofija, 1879.; „Samovila Makedonska“. Ot Gj. M. P.“, Sofija, 1879.

${ }^{10}$ Vidi: Ristovski, Blaže, „Đorđija M. Pulevski i negovite kniški“, Skopje, 1973., str. 29/30.
} 
referata, prepjeva. Knjižicu „Hrvati Madžarom“ napisao je kao hrvatski političar i član opozicije spram madžarskih tendencija prema Hrvatskoj. Od poznatijih mu pjesama spominjemo „Pređem slavjanskim“, „Vjekovi Ilirije“, „Javor“, „Javor i tamjanika“, „Primorac Danici“, „Riječ bratinska“. Pjesme mu je nakon njegove smrti sabrao i objavio sin Vladimir. ${ }^{11}$

Uvidom u te škrte biografije dvojice muškaraca koji žive i djeluju u 19. stoljeću dalo bi se naslutiti da nemaju ništa zajedničkog, dapače djeluju kao potpuno oprečni karakteri. Na hrvatskoj strani intelektualac, građanski političar, visoko rangirani bečki administrator, saborski zastupnik i u konačnici ban, a s druge strane autodidakt, zidar, komita, borac, ustanik u brojnim ratovima protiv Turske, vojvoda ustanički. Mažuranić je po prirodi smiren, povučen, ponekad i mučaljiv, obiteljski čovjek, više slušatelj nego govornik. Pulevski je vječno u pokretu, nemirna duha, čovjek od sablje i akcije, lukav, vješt, luđački odvažan, avanturist. Unatoč karakternim različitostima, zbližuje ih dosta toga.

Obojica su rodoljubi, političari, lingvisti, borci protiv tuđinske dominacije, pjesnici. Svojim djelom i životom obojica zauzimaju povlašteno mjesto u povijesti svojih naroda. Mažuranić cijeli svoj život provodi relativno mirno, u carevini kojoj je unatoč svom izraženom hrvatstvu i domoljublju bio sklon. Pulevski živi nemiran, opasan, avanturistički život. Sudjeluje u bunama i ratovima protiv Turaka u želji da njegova domovina dobije status slobodne i priznate zemlje. Mažuranić se za prava svog naroda bori na političkom planu, Pulevski sabljom i kuburom. Obojica imaju sposobnost jasnovidaca, ljudi koji imaju osjećaj za prošlost i budućnost svoga naroda. U tom kontekstu i djeluju, koristeći pritom i svoje pero, koje iza njih ostavlja poruke, kritike, osude, budi nadu i nudi umjetnički doživljaj.

Vrijedi napomenuti da su obojica bili leksikografi. Mažuranić je s Josipom Užarevićem objavio „Deutsch-Illiriyches Worterbuch“ (Njemačko-ilirski slovar) 1842. godine. Taj se rječnik s 4000 natuknica smatra prvim modernim hrvatskim rječnikom koji obiluje mnoštvom jezičnih novotvorenica, koje su ušle u svakodnevnu upotrebu. Pulevski 1873. godine objavljuje „Rječnik četiri jezika“ (Četirijazičnikot), ${ }^{12}$ potom 1875. godine „Rječnik od tri jezika“. ${ }^{13}$ Svojim rječnicima, a potom i početnicom „Slognica Rečovska“ Pulevski polako nastoji diferencirati makedonski jezik (govore) od srpskog i bugarskog i usmjeriti buduće jezikoslovce na centralne makedonske govore kao temelj budućem makedonskom književnom jeziku.

${ }^{11}$ Pjesme, Zagreb, 1895., 1924.

12 Rečnik od četiri jezika. I. Srpsko-Albanski, II. Arbanski-Arnautski, III. Turski, IV. Grčki. Skrojena i napisana ot Đorđa M. Pulevski, arhitekta u Galičnik okružje dubransko 1872. godine.

${ }^{13}$ „Rečnik od tri jezika. S. Makedonski, Arbanski i Turski“, knjiga II, napisao Đorđe M. Pulevski Mijak Galički. U Beogradu u Državnoj štampariji. 
Obojica dijele i sklonost prema narodnoj pjesmi, što se ogleda i u njihovu književnom radu. Pulevski u "Makedonskoj pesnarki“, uz svoje, objavljuje i desetak narodnih pjesama. O njegovoj sklonosti prikupljanju i zapisivanju narodnih makedonskih pjesama svjedoči i jedan od najpoznatijih sakupljača i izdavača makedonskih narodnih pjesama Kuzman Šapkarev, njegov stari prijatelj još iz doba Rusko-turskog rata. ${ }^{14} \mathrm{U}$ svojoj studiji pod naslovom „Narodni pesni i starini“ Šapkarev piše da poznaje jednog „galičnika“ koji ima mnogo materijala prikupljenih u debarskom kraju. U njega, piše Šapkarev, „ima pesni, pravi, običai, prikazni i razni drugi podatoci za geografskata položba na onie mesnosti. Ovoj čovek odamna se ima zanimavano so vakvi raboti i ima sobrano dosta bescenet materijal. Toj i po osloboduvanjeto se zanima so takvi raboti, šeta po ulicite i ćošinjata na Sofija, bara dulđeri i drugi rabotnici od raznite mesta na Makedonija za da zapišuva od niv pesni i dr.Toj ima mnogo materijal, no nema sredstva za da može da go izdadena svet. Samo eden mošne mal del, od toa materijal od novoto vreme izdade pominatata godina vo mnogu ograničen broj primeroci, povećeto od koi gi isprati vo Rusija do redakciite na vesnicite. " ${ }^{15}$ Šapkarev pod pojmom Galičnik podrazumijeva Pulevskog, koji se često koristio tim pseudonimom, označavajući tako kraj iz kojega je potekao. Istovremeno, uz informaciju da se Pulevski bavio prikupljanjem i zapisivanjem makedonskih pjesama, Šapkarev apostrofira staru boljku svih makedonskih sakupljača, počevši od braće Miladinova: nedostatak sredstava za objavljivanje takvih djela. U svojoj skromnoj, ali izuzetno važnoj zbirci, „Makedonska pesmarka“ Pulevski tiska petnaest pjesama, od kojih su neke njegove, no stil, jezik i rima većine od njih ukazuju na to da se radi i o narodnim pjesmama. Primjerice pjesma „Zdravica“, koja je uvrštena u „Pesmarku“, autentična je obredna narodna makedonska pjesma.

Iz rukopisne ostavštine sina Ivana Mažuranića - Vladimira vidljivo je da je njegov otac, kako on piše, „ljubio narodne pjesme“, međutim prezirao je prikupljanje narodnih pjesama. ${ }^{16}$ Prema Miloradu Živančeviću, koji se smatra u znanosti jednim od najboljih poznavatelja života i djela Ivana Mažuranića, Mažuranić je zapisivao narodne pjesme iz rodnog Vinodola, Metlike, Krašica, Volavje, Ribnika i Jasterbarskog. ${ }^{17}$ Malo je poznato, piše Živančević, da su braća Antun, Ivan i Matija prikupili jednu zbirku narodne poezije, i to s područja svoga zavičaja (Knjigu piše Deli-aga, Šator penje ban Sekula, Šeće Marko Kraljeviću). ${ }^{18}$ Uostalom u „Danici ilirskoj“ objavljena je njegova pjesma „Nenadović Rade“,

\footnotetext{
${ }^{14}$ Kuzman Šapkarev (1834. - 1909.), priučeni učitelj, folklorist, pisac udžbenika, pedagog. Vidi u: Goran Kalogjera, Makedonsko XIX. stoljeće, Zajednica Makedonaca u Republici Hrvatskoj, Rijeka, 2011., str. 176-184.

${ }^{15}$ K. (Šapkarev) Narodni pesni i starini, „Marica“, V, 377, 13. IV, 1882., 5.

16 Živančević, Milorad, Smrt Smail-age Čengića Ivana Mažuranića, Biblioteka PKD, Beograd, 1982.

${ }^{17}$ Isto.

18 Isto.
} 
koje je ispjevana po ugledu na narodnu pjesmu. Ne zaboravimo i podatak da mu je najranija literatura u djetinjstvu bila Kačićeva pjesmarica.

Poticaj pisanju Mažuranićeva epskog spjeva te poeme i pjesama Pulevskog povijesni su događaji. Za Pulevskog je to Berlinski kongres (1878.), koji revidira Sanstefanski mirovni dogovor, po kojem je Rusija proširila svoj utjecaj na Balkan, a Bugarska postala neovisna kneževina u čiji je teritorij uključena i Makedonija. Kao i većina njegovih suboraca, revoltiran odlukama Berlinskoga kongresa, koji je onemogućio Makedoncima oslobađanje od Turaka, bar u okviru Bugarske, Pulevski se odlučuje na oružani otpor Turcima i sudjeluje u Kresnenskom ustanku. Istovremeno progovara i kao pjesnik te u razdoblju između Berlinskog kongresa i Kresneskog ustanka uspijeva objaviti poemu "Samovila makedonska“ i zbirčicu autorskih i narodnih pjesama "Makedonska pesnarka“. Njegova je poezija reakcija na nepravdu europskih sila prema Makedoncima. Ona je podjednako optužujuća, elegična, na trenutke i patetična, ali i revolucionarna jer Pulevski uviđa da je sazrelo vrijeme da se Makedonija oružjem izbori za svoj opstanak.

Kod Mažuranića je također poticaj i inspiracija povijesni događaj, naravno ne toliko važan u svjetskim okvirima kao Berlinski kongres, ali za jug Balkana itekako je važan jer se radilo u ubojstvu poznatoga turskog age. Vijest koju je objavio „Srbski narodni list“ pod naslovom „Bosna i Hercegovina 1840.“ bila je izvješće o ubojstvu Smail-age Čengića: „U Hercegovini sad je velika smutnja. I Smail aga Čengić, onaj slavni i proglašeni junak turski, zapovjednik oružja Gadskog, poginuo je 30. rujna..." ${ }^{19}$ । Smail-aga Čengić, paša hercegovački, bio je poznati ratnik i vojskovođa. Zajedno s Ali-pašom Stočevićem ugušio je 1832. godine ustanak bosanskog bega Husein-bega Gradašćevića ${ }^{20}$, a 1836. godine proslavio se na na Grahovu, u bitci u kojoj je pobijeno više članova crnogorske vladarske kuće Petrovića, uglavnom rođaka vladike Njegoša. Crnogorci su se osvetili prevarom. Drobnjački knez Đoko Malović napisao je Smail-agi provokativno pismo u kojem ga optužuje za kukavičluk jer godinama ne dolazi u Drobnjake po harač. Aga je nasjeo na provokaciju, otišao put Drobnjaka, ulogorio se na Mljetičku kod Šavnika, gdje su ga napali Crnogorci i ubili.

Svrha rada nije ulaziti u detaljnije analize hrvatskog epskog spjeva i makedonske poeme i pjesama, nego izvući određene poruke koje obojica autora šalju sunarodnjacima i svijetu koji ih okružuje, posebice europskim silama, koje su u potpunosti nezainteresirane za probleme naroda pod turskim jarmom. Da su južnoslavenski narodi uvijek bili mete iznude, tlačenja, iskorištavanja, razaranja, alijenacije, uvidjeli su ne samo Mažuranić i Pulevski već i njihovi pjesnički istovremenici: France Prešern, Petar Petrović

\footnotetext{
${ }^{19}$ Srbski narodni list, br. 87. od 7 (19) oktobra 1840. Tekst su objavile i llirske narodne novine u dopisu od 17. studenoga iste godine.

${ }^{20}$ Taj je događaj u formi romana objavio Josip Eugen Tomić, Zmaj od Bosne, MH, Zora, Zagreb, 1970.
} 
Njegoš i Grigor Prličev. ${ }^{21}$ Svi su ti romantičarski pjesnici u eri buđenja svojih nacija osjećali prijetnju koja je dolazila od Turskog Carstva, ali i europske gramzljivosti, perfidnosti i nezainteresiranosti. Stoga nimalo ne začuđuje kada se Pulevski stihom punim žuči gnjevno obrušava na takvu Europu:

„Čujte braća naši jevropski hristijani,

Da je naša sudba nami dosadila

I mije hošteme našu domovinu.

Evo dneska i makedonskej kralevini naši braća tužat,

Zašto samo paze pod ropstvo ostavajet,

Zašto i mije hošteme svoju domovinu!"

(„Makedoncim uv prilog“)

To je traženje pravde ogorčenog ustanika, koji optužuje Europu zbog njezina odnosa prema Makedoniji koja također zaslužuje slobodu. Očaj i bijes staroga Mijaka pojačavaju i sljedeći stihovi ispjevani u duhu narodne tužbalice:

Makedonski majki pištat, a Jevropu milno moljat:

„O Jevropo hristijanska, dal? Ne slušaš naši plač?

O, Jevropo mila majko, što ni ostavi pod turska vlast?“

(„Plačeešti tožit“)

Spoznaja da Makedonci voljom europskih diplomata ostaju pod Turcima užasava pjesnika, koji u stihu upotrebljava formu kolektivnoga tugovanja da bi emotivno osnažio svoju optužbu Europi: „zašto ste nas ostavili pod turskom vlašću?“. Strahovladu i teror osmanlijske vlasti nad makedonskim življem Pulevski dojmljivo iskazuje u optužujućim stihovima poeme „Samovila makedonska“, koji izražavaju sav užas i strahote kroz koje su kao roblje prolazili makedonske žene, majke, muškarci i svećenstvo:

„Svi zlotvori voz sela šetat za da pravi nasilnistvo,

Ta v či(j) dom najdat mladi devojki - gi isturčije,

$\checkmark$ koj dom najdat mladi nevesti - možite im ubivajet,

A nevestite vseh so sila gi obesčastat.

Koja žena im se ne ne davat bezzakonno da ju siluvat

Suštih ženi zlodelnici gi nih ubivajet,

A slavjanskih svjaštenici za buntovnici gi obvinuvat,

Ta gi praćat vo Hazija v zatočenie..."

\footnotetext{
${ }^{21}$ Mislim pritom na Prešernov „Sonetni venec“, Njegošev „Gorski vijenac“ i Prličevog „Serdara“.
} 
Nakon što je prokazao europsku izdaju Sanstefanskog dogovora, teror, nasilje, ugnjetavanje i smrt, koji dolaze od turske ruke, Pulevski se poput Mažuranićeva svećenika na Morači obraća svojim sunarodnjacima stihovima koji nisu više molba i pokuda Europi, nego poziv na slogu, zajedništvo, kršćansku vjeru i u bitku do pobjede:

„Bratije naši Makedonci od pravoslavnu veru,

Da se svi složime, junački borime,

Kako naši stari pod car Aleksandrom,

Povtor spomen svojim imjam po nas ostavime

Istoriju staru da ja oživime...

Pradedovi naši stari makedonski

Tije nami dobor spomen ostavile

Ovim delom sega koski im prelejeme

I sve da činime da ih posvetime

I zlatni im venci mije napravime

Vojnomakedonski barjak stari razvijeme

Ta na platno obraz svjatogeogrevski

A od drugu stranu svjatodimitrievski

Ta da se borime pod svjatim znamenjem“

(,Makedoncim uv prilog“)

Autoru teksta jasno je da će predstavljeni stihovi zvučati grubo, nerimovano, jezično arhaično, međutim čitatelj bi trebao shvatiti da su pjesme Pulevskog produkt 19. stoljeća, razdoblja u kojem Makedonci nemaju normirani književni jezik i da se svi oni koji pišu i objavljuju u tom razdoblju trude stvoriti jezičnu bazu budućem makedonskom jeziku. Uprkos tomu Pulevski piše strastveno, politički angažirano, nadahnuto i buntovno, pod očitim utjecajem narodne pjesme. On ne poznaje tehnologiju rime, akcentuaciju, već prati melodiju narodne pjesme, dodavajući svojim pjesmama osobne napomene kako bi se pjesme trebale čitati odnosno pjevati. Naime, treba znati da je većinu pjesama iz „Makedonske pesmarice“ i poemu „Samivila makedonska“ makedonski narod prihvatio kao svoje, narodne pjesme i da su pjevane tijekom i poslije njihova objavljivanja. Pulevski je očito kao jezičar bio na dobrom putu jer je isticao centralne makedonske dijalekte i rječnik svih makedonskih govora, što ga približava Krsti P. Misirkovu ${ }^{22}$ i njegovim tezama o budućem makedonskom književnom jeziku, koji je nakon Drugog svjetskog rata Blaže Koneski u svojoj gramatici i realizirao. ${ }^{23}$

22 Krste Petkov Misirkov, autor brošure „O makedonskim stvarima“ u kojoj se nalazi pet rasprava od kojih je za budućnost normiranja makedonskog jezika najvažnija studija Nekoliko riječi o makedonskom jeziku, detaljnije vidi u: Goran Kalogjera, Makedonsko XIX. stoljeće, Zajednica Makedonaca u Republici Hrvatskoj, Rijeka, 2011., str. 217-220.

${ }^{23}$ Blaže Koneski - esejist, pjesnik, književni povjesnik, kritičar, autor prve gramatike makedonskog književnog jezika. 
Analizirajući njegov skromni poetski opus, razvidno je da Pulevski pripada generaciji osviještenih Makedonaca koji su shvatili da neće biti učinkoviti u pitanju neovisnosti oslone li se na politike europskih zemalja. Zato su motivi njegovih pjesama Sanstefanski dogovor, Berlinski kongres, nezaintersirana Europa i Rusija, kao mogući zaštitnik makedonskih interesa. Njegov povik i poziv na oružani otpor jedino je racionalno rješenje do kojega Makedonci dolaze, izigrani od europskih sila. Njegove pjesme koncipirane su prvenstveno kao protest kolektiva prema tuđinu. One su istovremeno snažna osuda nezaintersiranoga svijeta i turskoga zuluma. Dakako da su one stilski nedotjerane, prepune srbizama i bugarizama, ponekad i patetične, no i danas dovoljno razumljive pa da se shvate njegove osnovne poruke Europi, susjedima i turskom ugnjetaču.

O istim problemima progovara i hrvatski pjesnik Ivan Mažuranić. On to realizira na visokom estetskom i umjetničkom nivou, izražajnije, stilski ujednačajnije, s obiljem metaforike, u duhu narodne pjesme i dubrovačke poezije. Poput Pulevskog, i Mažuranić će opjevati turski bijes nad nemoćnom rajom:

„Krcnu kolac nekoliko puta,

Zviznu pala nekoliko puta,

Zadrhtaše ta vješala tanka,

Al ne pisnu Crnogorčad mlada, Niti pisnu, niti zubi škrinu.

Proz poljanu mrka krvca teknu,

Niti pisnu, niti zubi škrinu.

Poljana se napuni tjelesa,

Niti pisnu, niti zubi škrinu."

(„Agovanje“)

Za razliku od Pulevskog koji se tijekom svojih hajdučkih i komitskih dana svaki dan suočavao s turskim grozotama na teritoriju rodne mu Makedonije, Ivan Mažuranić nikada nije putovao u Bosnu, Crnu Goru ili tursku carevinu. Unatoč neospornoj pripremi za epski spjev, koji je trajao, izvori su mu mogli biti brojni: putopisi, članci iz tiskovina; premda bih prednost dao informacijama koje je dobio od prebjega u Hrvatsku, s kojima je kao karlovački kurator svakako dolazio u dodir, i izvješću braće Matije iz Bosne te Antuna iz Crne Gore. Kao što Pulevski rezignirano, apatično i optužujuće govori o „Jevropi“, tako će i Mažuranić u „Četi“ kroz usta svećenika iznijeti svoj stav, zapravo oštru i optužujuću kritiku indiferentne i samodostatne Europe, koja na njegove zemljake i ostali slavenski svijet pod Turcima gleda kao na barbare, primitivce, divljake: 


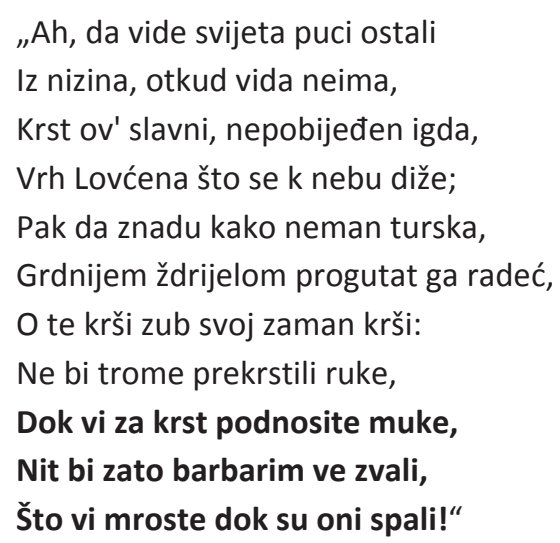

(„Četa“)

Mažuranić je ovim stihovljem, kako kaže Barac, svjesno i oštro podvukao razliku između svijeta povlaštenih i između maloga svijeta, boraca za slobodu. Mažuranićev spjev znači poklik na borbu protiv nasilja. U njemu je oštro istaknuta razlika između dva morala, morala sile i užitka na račun drugoga i morala odricanja žrtve za cjelinu. „Svećenikove riječi neosporna su sinteza svih najboljih patriotskih čuvstava koja ostaju karakteristika svih slobodoljubivih ljudi u svim vremenima. "24 Stihom „što vi mroste dok su oni spali“ Mažuranić udara pljusku Europi, koju je imao prilike upoznati i istovremeno iskazuje pijetet svim žrtvama koje su pale zbog njene samodatosti i indiferentnosti. Kao i Barac, Gane Todorovski, vrsni poznavatelj hrvatske književnosti, pa tako i Mažuranića, ima stav o funkcionalnosti i svrsi njegova epskog spjeva: „Ova oddalečuvanje od istoriskata vistina (dali svesno ili poradi nepoznavanje na site podrobnosti?), e rešavačko za krajniot efekt na poemata. Rešavačko e zatoa što toj preku toa smognuva da se odeli od konkretniot nastan, te preko poopšti pouki od nego da progovori za narodniot strmež za slobodata. Očigledno sam Mažuranić ne držel mnogu do toa da go opee samiot istoriski čin preko site negovi podrobnosti, tuku go ispolzuval slučajot preko smrtta na Smail aga da raskaže za patila na svoj sopstven narod pod tuđinska vlast, za negoviot heroizam i negovata nepokolebliva vera vo slobodata vo urnuvanjeto na tiranija i ugnetuvanjeto". ${ }^{25}$

Živančević dobro procjenjuje kada piše da takvi tekstovi nastaju i pojavljuju se u jasno omeđenom razdoblju, koje se u većini južnoslavenskih naroda naziva preporodnim i u vezi je s buđenjem nacionalne svijesti i tada formiranjem modernih nacija u Europi. ${ }^{26}$ Problematiku otpora tuđinu, borbu za slobodom i priznavanjem vlastitih nacionalnih entiteta, osjećaju i iskazuju svi veliki pjesnici u bliskom dodiru s turskom okupacijom,

\footnotetext{
${ }^{24}$ Antun Barac, Hrvatska književnost, knjiga 1. Književnost ilirizma, Zagreb, 1964., str. 220-221.

25 Gane Todorovski, Neodložni ljubopitstva, Misla, Skopje, 1987., tekst: Ličnost i deoto na Ivan Mažuranić, str. 7-39.

${ }^{26}$ Milorad Živančević, Smert Smail age Čengića, Ivana Mažuranića, Beograd, PKD, 1982.
} 
zapostavljeni od europskoga interesa. Patnje bosanske, crnogorske, srpske, makedonske i bugarske raje bit će temeljni motivi njihovih epskih spjevova i poema. Hegemonističke politike i propagande ostavljaju svoje tragove u nacionalnim bićima porobljenih naroda, koji tijekom 19. stoljeća odlučuju reći konačno - DOSTA. Poruke koje šalju Mažuranić i Pulevski u svojim djelima identične su, tematski i sadržajno vrlo bliske. Svode se na osudu tiranije, kritiku europske bezobzirnosti i nezainteresiranosti, potenciraju hrabrost svojih naroda unatoč teroru i mrcvarenju te u konačnici i jedan i drugi izlaz iz trenutačnog stanja vide u oružanoj borbi. Mažuranić to iskazuje porukom o sili koja nije za svagda i jednom mora pasti, koja nije ništa blaža od one koju šalje Pulevski:

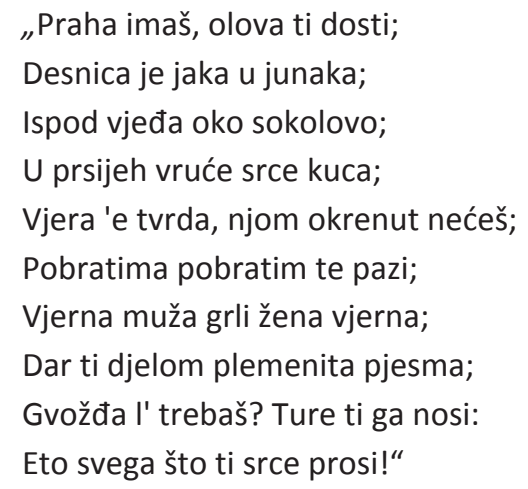

Pulevski, što je s obzirom na njegovu situaciju razumljivo, ogorčeniji je, radikalniji i revolucionarniji. Pozivajući se na Aleksandra Makedonskog, u kojem vidi mobilizirajući faktor za pokretanje makedonskih masa na ustanak i njihovo objedinjavanje pod zajedničkim stijegom, Pulevski zagovara zajedništvo u narodu i vjeri, kao temeljnim čimbenicima uspjeha u borbi za slobodu i neovisnost:

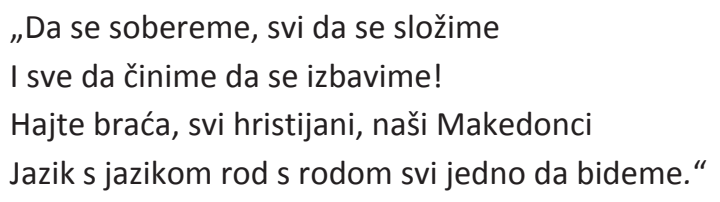

(,Makedonci uv prilog“)

Ako se, koliko je to moguće (a trebalo bi za to imati razumijevanja), zanemari ljepota Mažuranićeva jezika u odnosu na stih Pulevskog, onda vidimo da iz njihovih poruka progovara univerzalna poruka o slobodi, pravdi, jednakosti i pravu da se ta sloboda brani svim raspoloživim sredstvima. Premda se nisu poznavali ni ikada sreli, vjerojatno ni čuli jedan za drugoga, oni neovisno o svom obrazovanju i statusu, kao umni i pragmatični ljudi svoga vremena, zagovaraju one univerzalne poruke humanog čovječanstva na temu da svaki narod ima pravo na svoju slobodu, svoju neovisnost, nacionalnost, jezik i u konačnici svoju državu. 


\section{Zaključak}

Hrvatski i makedonski pjesnik Ivan Mažuranić i Đorđija M. Pulevski u svojim djelima osuđuju turski teror nad nevinim pučanstvom i svojim stihovima kritiziraju politiku europskih sila, koje ga nisu našle načina prekinuti. Ep „Smrt Smail-age Čengića“ i rukovet pjesama u „Makedonskoj pesnarki“ i elegiji "Samovila makedonska“ snažan su i impresivan protest protiv tiranije i sile, ali i osuda nezainteresirane Europe, koja se distancirala i nezainteresirano pratila patnje nevinih i tako postala sudionikom turske tiranije, terora, ubojstava i pljački. Obojica pjesnika svojim stihovima veličaju hrabrost, junaštvo i slobodarski duh podjarmljenih naroda, iskazuju svoje ogorčenje prema slobodarskoj Europi i njezinoj politici nemješanja, ali šalju i poruku o oružanoj borbi, kao jedinom mogućem rješenju u postizanju željene slobode.

\section{POPIS LITERATURE}

\section{Barac 1964}

Barac, Antun, Hrvatska književnost od preporoda do stvaranja Jugoslavije, knjiga 1. Književnost ilirizma, Zagreb 1964.

Frangeš i Živančević 1974

Frangeš, Ivo; Živančević, Milorad, Povijest hrvatske književnosti, knjiga 4, Liber, Mladost, Zagreb 1974.

Koneski 1959

Koneski, Blaže, Kon makedonskata prerodba, Makedonskite učbenici od 19. vek, vtoro izdanie, Institut za nacionalna istorija, Skopje 1959.

Polenaković 1941

Polenaković, Haralampije, Mijački leksikograf Đorđe M. Pulevski, „Glas Juga“, Skopje 1941.

\section{Ristovski 1973}

Ristovski, Blaže, Đorđija M. Pulevski i negovite kniški „Samovila Makedonska" $i$ „Makedonska pesnarka", Institut za folklor, Skopje 1973.

Smiljanić-Bradina 1927

Smiljanić-Bradina, Tomo, Đorđe $M$. Puljevski (Mijak Galički), „Južni Pregled“, 1, 2-3, Skopje 1927.

\section{Šicel 1997}

Šicel, Miroslav, Hrvatska književnost 19 i 20. stoljeća, Školska knjiga, Zagreb 1997.

Todorovski 1987

Todorovski, Gan, Ličnosta i deloto na Ivan Mažuranić, Neodložni ljubopitstva, Misla, Skopje 1987. 


\section{SAŽETAK}

Premda se Ivan Mažuranić, hrvatski pjesnik i ban, i Đorđija Pulevski, mijački zidar i ustanički vojvoda, nikada nisu u svojim životima susreli, osobnim su primjerom kao časni ljudi i pjesnici u svojim djelima slali univerzalne poruke o pravu svakog naroda na slobodu, vjeru, jezik i državu.

\section{SUMMARY}

Relationship to freedom, tyranny and the european powers in the works by Ivan Mažuranić and Đorđija Pulevski

Although Croatian poet Ivan Mažuranić and Đorđija Pulevski, Macedonian insurgent never met, they both sent out universal messages in their literary works on the right of every nation to freedom, religion and state.

Keywords: poem, epic poem, Pulevski, Mažuranić, the Turks, "Macedonian songbook", "A Macedonian Fairy", "The Death of Smail-Aga Cengić", Europe 